\title{
Mimosoideae (Leguminosae) do litoral paraense
}

\author{
Julio dos Santos de SOUSA ${ }^{1}$, Maria de Nazaré do Carmo BASTOS², Antônio Elielson Sousa ROCHA ${ }^{3}$
}

\begin{abstract}
RESUMO
Este trabalho consiste no tratamento taxonômico de Mimosoideae nas restingas do litoral paraense, uma vez que estas são pouco conhecidas sob esse aspecto. Esse estudo abrangeu a análise do material proveniente de coletas e exsicatas dos herbários MG e IAN, além de literatura especializada. São apresentadas chave de identificação, descriçôes e ilustraçôes dos táxons, bem como dados adicionais sobre distribuição geográfica, comentários, período de floração e frutificação e hábitat das mesmas. O fruto foi o caráter de maior destaque na separação dos táxons. Os resultados evidenciaram a presença de sete espécies, três variedades e uma subespécie, distribuídas em seis gêneros. Inga thibaudiana subsp. thibaudiana e Mimosa candollei, são novos registros para o litoral do Pará. O gênero Inga Mill. foi o mais representativo com cinco espécies. Entada polystachya var. polystachya e principalmente Chloroleucon acacioides apresentaram distribuição mais ampla e a formaçáo floresta de restinga foi o ecossistema que apresentou o maior número de espécie.
\end{abstract}

PALAVRAS-CHAVE: Mimosoideae, taxonomia, morfologia, restinga, Amazônia.

\section{Mimosoideae (Leguminose) on the coast of Pará}

\section{ABSTRACT}

This study deals with the taxonomic treatment of Mimosoideae on the coastal sandbanks of Pará, since they are poorly known under this aspect. That study includes the analysis of botanical material from new collections and specimens of the MG and IAN herbariums, besides that found in specialized literature. Are given identification key, descriptions, and illustrations of the taxa, as well as data concerning geographical distribution, additional comments, flowering and fructification period, and habitat of the species. The fruit has the quality of great prominence in the separation of taxa. The results pointed out the presence of seven species, three varieties and one subspecies, distributed in six genera. Inga thibaudiana subsp. thibaudiana e Mimosa candollei are new records for the sand coast of Pará. The genus Inga Mill. was the most representative with five species. Entada polystachya var. polystachya and specially Chloroleucon acacioides presented the widest distribution, and sandbank forest formation was the ecosystem which had the largest number of species.

KEYWORDS: Mimosoideae, taxonomy, morphology, sandy coastal, Amazonia.

1 Museu Paraense Emílio Goeldi. E-mail: jssousa@museu-goeldi.br

2 Museu Paraense Emílio Goeldi. E-mail: nazir@museu-goeldi.br

${ }^{3}$ Museu Paraense Emílio Goeldi. E-mail: asrocha@museu-goeldi.br 


\section{INTRODUÇÃOO}

Leguminosae com cerca de 727 gêneros e 19.325 espécies é considerada a terceira maior família entre as Angiospermas, depois das Asteraceae e Orchidaceae (Lewis et al., 2005). Apresenta distribuição cosmopolita, com centro de diversidade nos trópicos (Lewis, 1987).

No Brasil está representada por cerca de 200 gêneros e 1500 espécies (Sousa e Lorenzi, 2005), distribuídas em quase todas as formaçóes vegatacionais (Lima, 2000). Na Amazônia, a família conta com cerca de 148 gêneros, que corresponde a quase um terço do total da família (3.100 táxons específicos e infraespecíficos), com padrão de distribuição disjunta e/ ou contínua e cerca de 21 gêneros provavelmente endêmicos (Silva e Souza, 2002).

Tradicionalmente, Leguminosae está divida em três subfamílias: Caesalpinioideae, Mimosoideae e Papilionoideae (Polhill e Raven, 1981). Mimosoideae apresenta quatro tribos, 78 gêneros e aproximadamente 3.270 espécies (Lewis et al., 2005), distribuídos nas regióes tropicais, subtropicais e cálido-temperadas (Barroso et al., 1991). Segundo Lewis et al. (2005) Acacia Mill., com cerca de 1.450 espécies, Mimosa L. com 500 e Inga Mill. com 300, estấo entre os 20 maiores gêneros de Leguminosae.

Apesar de ser uma subfamília estudada por vários autores, ainda são poucos os trabalhos com ênfase no litoral, especialmente no paraense. Portanto, levando-se em conta a relevância da subfamília e a necessidade de estudos na área, o presente trabalho teve como objetivo principal realizar o tratamento taxonômico das Mimosoideae ocorrentes nas restingas do Estado do Pará, fornecendo informaçôes para uma melhor identificação dos táxons e subsídios aos planos de manejo das áreas de proteção ambiental (APAs), deste ecossistema.

\section{MATERIAL E MÉTODOS}

Localização e caracterização da área de estudo - O litoral paraense possui $500 \mathrm{~km}$ de extensão e situa-se entre a baía de Marajó e a foz do rio Gurupi ( $46^{\circ}$ a $48^{\circ} \mathrm{W}$ e $0^{\circ} 30^{\prime}$ a $1^{\circ} \mathrm{S}$ ), o que corresponde a 8,6\% da área total do Estado (Furtado, 1987). É bastante recortado, com uma sucessão de pequenos estuários, formando baías como as de Marapanim, Maracanã, São João de Pirabas e Caeté, margeadas por penínsulas e uma série de ilhas estendidas até o oceano, onde se destacam as de Mutucal, Maiandeua, Marieta e Coqueiro (Costa Neto, 1999). O clima é do tipo Awi da classificação de Köppen, caracterizado por precipitação alta e constante $(>1.500 \mathrm{~mm} /$ ano), altas temperaturas $\left(>20^{\circ} \mathrm{C}\right)$ e baixa variação térmica (Souza Filho et al., 2005).

A cobertura das restingas do Estado do Pará está distribuída em seis formaçóes vegetais distintas: halófila, psamófila reptante, brejo herbáceo, campo de dunas, formação aberta de moitas e floresta de restinga (Amaral et al., 2008).

Métodos - O estudo foi baseado em material herborizado, incorporado nos herbários do Museu Paraense Emílio Goeldi (MG) e da Empresa Brasileira de Pesquisa Agropecuária/ Embrapa Amazônia Oriental, Belém, Pará, Brasil (IAN) e coletas realizadas durante três excursóes $(20 \mathrm{a} 28$ de abril de 2006, 25 a 30 de novembro de 2006 e de 15 a 22 de maio de 2007), tendo em vista o período de floração e frutificação. Para a coleta, preservação e herborização dos espécimes foram adotadas as recomendaçóes técnicas propostas por Fidalgo e Bononi (1984). A terminologia utilizada para as estruturas morfológicas está baseada nos trabalhos de Radford et al. (1974), Harrington e Durrell (1957), indumento; Stearn (1992), Rizzini (1977), folíolos e foliólulos; Garcia (1998), Irwin e Barneby (1982), nectário foliar e Barroso et al. (1999), fruto. A identificação dos táxons foi realizada por comparação com o material herborizado e certificado por especialistas, análise dos tipos, quando disponíveis, chaves analíticas, diagnoses e descriçôes existentes na literatura. As ilustraçóes foram feitas, pelo autor, a olho nu (partes vegetativas) e com o auxílio de um estereomicroscópio ZEISS, acoplado à câmara clara, em diversas escalas de aumento (partes reprodutivas), utilizando-se a técnica de nanquim, sobre papel vegetal, à mão livre.

Neste trabalho, são acatadas as consideraçóes de Lewis et al. (2005), que mantêm Leguminosae como uma única família, dividida em três subfamílias.

\section{RESULTADOS E DISCUSSÃO}

A subfamília está representada na restinga do estado do Pará por seis gêneros, sete espécies, três variedades e uma subespécie; sendo Inga o gênero mais representativo, com quatro espécies e uma subespécie. O fruto é o principal caráter diagnóstico das Mimosoideae do litoral paraense.

Chave para identificação dos táxons de Mimosoideae do litoral paraense

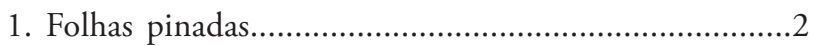

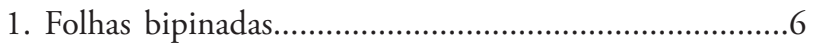

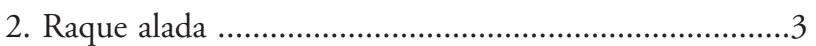

2. Raque não alada...........................................................

3. Pecíolos glabros; raque glabra; folíolos obovados, com ápice obtuso a arredondado; brácteas espatuladas; ovário pubescente................................... Inga splendens Willd.

3. Pecíolos pubescentes ou tomentosos; raque pubescente, tomentosa a vilosa; folíolos elípticos, ovados ou ovadolanceolados, com ápice agudo a estreitamente atenuado; brácteas ovadas, lineares ou lanceoladas; ovário glabro..................... 4 
4. Estípulas lanceoladas a elípticas, persistentes; pecíolos alados; nectários foliares pateliformes ou ciatiformes; folíolos com 2 jugas, coriáceos; inflorescências espiciformes; legume nucóide castanho escuro, glabro......... Inga pilosula (Rich.) J.F. Macbr.

4. Estípulas ovadas ou deltóides, caducas; pecíolos não alados; nectários foliares cupulares; folíolos com 3-6 jugas, cartáceos; inflorescências em racemos; legume nucóide ferrugíneo, viloso. Inga cayennensis Sagot ex Benth.

5. Folíolos 1-3 jugas, cartáceos, glabros, ápice longo e estreitamente acuminado; inflorescências em umbelas; brácteas linear-espatuladas a elípticas; legume nucóide glabro.

Inga heterophylla Willd.

5. Folíolos 4-6 jugas, coriáceos, esparsamente estrigosos na superfície adaxial e seríceo-estrigosos na superfície abaxial, ápice agudo ou atenuado; inflorescências espiciformes; brácteas ovadas; legume nucóide velutino... Inga thibaudiana DC. subsp. thibaudiana

6. Nectários foliares presentes. ...7

6. Nectários foliares ausentes. ..8

7. Ramos espinescentes; folhas com 5-7 jugas; foliólulos 10-36 pares por pina, lineares a linear-oblongos; ovário truncado; fruto do tipo legume nucóide, helicoidal....

Chloroleucon acacioides (Ducke) Barneby \& J.W. Grimes

7. Ramos inermes; folhas com 1(-2) jugas; foliólulos 2-3 pares por pina, ovados a elípticos; ovário elipsóide; fruto do tipo legume, curvado.

Abarema cochleata (Willd.) Barneby \& Grimes var. cochleata

8. Acúleos presentes; foliólulos sensitivos. .9

8. Acúleos ausentes; foliólulos não sensitivos 10

9. Ramos tetragonais; pecíolos aculeados; corola 5-lobada; estames 10; craspédio linear-tetragonal, não dividido em artículos monospérmicos, réplum glabro e aculeado; rostro 0,9-2,8 cm compr..... Mimosa candollei R. Grether

9. Ramos cilíndricos; pecíolos inermes; corola 4-lobada; estames 4; craspédio oblongo, dividido em artículos monospérmicos, réplum híspido e inerme; rostro ausente.....

....Mimosa pudica var. unijuga (Walp. \& Duchass.) Griseb.

10. Liana ou arbusto escandente; folhas 3-4 jugas; foliólulos oblongos; inflorescências terminais em densas panículas espiciformes; corola dialipétala; estames 10, livres; anteras com glândulas apicais caducas; fruto do tipo craspédio......... Entada polystachya (L.) DC. var. polystachya 10. Árvore ou arbusto ereto; folhas unijugadas; foliólulos rombóide-oblongos a subfalcados; inflorescências axilares, capituliformes; corola gamopétala; estames 15-20, em tubo estaminal, anteras eglandulosas; fruto do tipo legume Calliandra surinamensis Benth.

\section{DESCRIÇÃO DOS TÁXONS}

1. Abarema cochleata (Willd.) Barneby \& Grimes var. cochleata. Mem. New York Bot. Gard. 74(1): 85. 1996. Figura 1

Árvore até ca. $15 \mathrm{~m}$ de alt. Ramos cilíndricos, glabros ou tomentosos, inermes. Estípulas 0,5-2 mm compr., ovadas, lanosas, caducas. Pecíolos 0,6-3 cm compr., cilíndricos a canaliculados, não alados, glabros ou lanosos. Nectários foliares 0,7-1 mm diâm., cupulares. Raque 1,9-3 cm compr., cilíndrica a canaliculada, não alada, glabra. Folhas bipinadas 1(-2) jugas; pina 4-12,7 cm compr.; foliólulos 2-3 pares por pina, 2,1-6,8 cm compr., 1,1-3,6 cm larg., não sensitivos, subcoriáceos, discolores, ovados a elípticos, ápice agudo a acuminado, base aguda, obtusa ou arredondada, glabros, nervuras secundárias 7-9 pares, arqueado-ascendentes. Inflorescências capituliformes, axilares ou terminais; pedúnculos $0,7-3 \mathrm{~cm}$ compr., cilíndricos a canaliculados, glabros; brácteas 0,5-1,5 mm compr., ovadas ou espatuladas, pubescentes, persistentes ou caducas. Flores curtamente pediceladas a sésseis; cálice $2-4 \mathrm{~mm}$ compr., campanulado, lobos 5, puberulentos; corola gamopétala, 4,5-8 mm compr., campanulada, lobos 5, puberulentos; estames 12-20, tubo estaminal 3-12 mm compr., incluso ou curtamente exserto, filamentos livres $12-15 \mathrm{~mm}$ compr., anteras eglandulosas; ovário 1,5-1,8 mm compr., elipsóide, glabro, estilete filiforme, excedendo os estames. Legume 8-10 cm compr., 1,2-1,5 cm larg., curvado, dilatado ao redor das sementes, castanho, reticulado ou com nervuras oblíquas, coriáceo, glabro, ápice e base agudos, margem delgada e ondulada.

Distribuição: Abarema cochleata var. cochleata é comum na Amazônia brasileira, ocorrendo desde a jusante do rio Trombetas à foz do rio Tapajós, e daí para o leste, ao longo da costa até o Maranhão central. Ocorre em mata primária, capoeira, ilhas e ao longo da margem de savanas, ocasionalmente em campinarana ou bosques pantanosos (Barneby e Grimes, 1996), sendo muito freqüente no litoral paraense (Ducke, 1949), na formação aberta de moitas e floresta de restinga.

Material examinado: BRASIL. Pará: Bragança, restinga, 21.IV.2006, fr., Sousa 03 (MG); Curuçá, praia do Sino, restinga, 14.XII.1992, fl. e fr., Bastos et al. 1302 (MG); Maracaná, ilha de Algodoal, restinga da praia da Princesa, 19.VIII.1994, bot., idem 1730 (MG); ibidem, floresta de restinga, 26.XI.2006, fl., Sousa et al. 13 (MG); ibidem, ilha de Maiandeua, floresta de restinga, 11.III.1995, fr., Lobato 1015 (MG); ibidem, 5.X.2006, fl., Furtado \& Rocha 9 (MG); ibidem, Fortalezinha, formação aberta de moitas, 16.V.2007, fr., Sousa et al. 35 (MG); ibidem, restinga da praia da Marieta, 07.IX.1994, bot., Bastos et al. 1760 (MG).

Nomes Vulgares: “ingá-de-porco”, “ingarana” e "ingáde-sapo". 
De acordo com Barneby e Grimes (1996) a var. cochleata se diferencia da var. moniliformis por apresentar as valvas do fruto coriáceas (quando maduro), menores que $2 \mathrm{~mm}$ de espessura na constrição e exocarpo grosseiramente reticulado ou oblíquo. É facilmente reconhecida no litoral paraense por ser a única Mimosoideae que apresenta 2-3 pares de foliólulos discolores por pina.

Foram observados indivíduos de $A$. cochleata var. cochleata em floração nos meses de agosto a dezembro e em frutificaçáo nos meses de dezembro a maio.

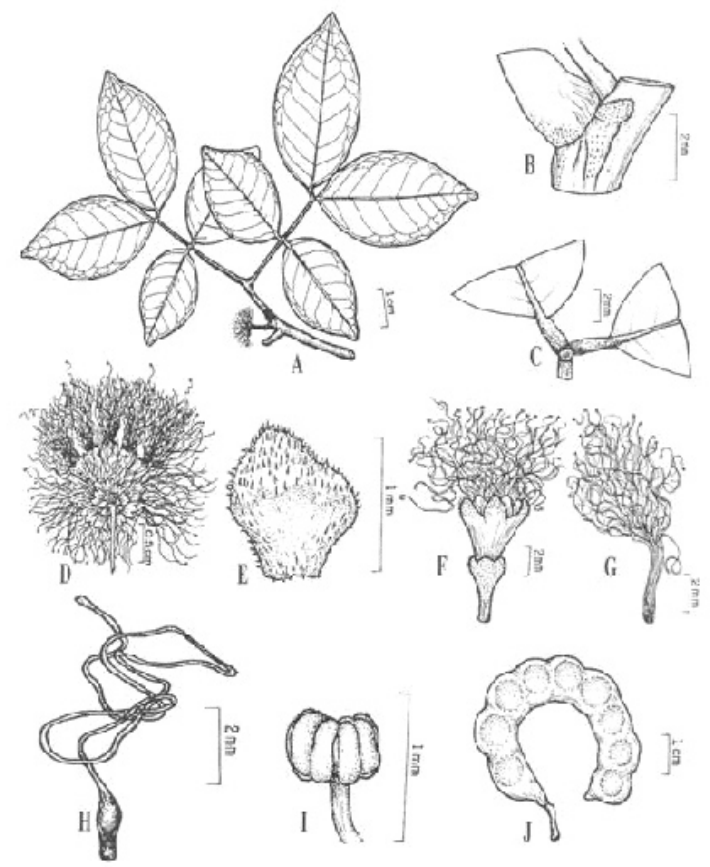

Figura 1 - Abarema cochleata (Willd.) Barneby \& Grimes var. cochleata: A. Folha e inflorescência; B. Inserção da estípula; C. Nectário foliar; D. Inflorescência; E. Bráctea; F. Flor; G. Androceu; H. Gineceu; I. Detalhe do estame; J. Fruto.

2. Calliandra surinamensis Benth., London J. Bot. 3: 105. 1844. Figura 2

Árvore ou arbusto ereto até ca. $3 \mathrm{~m}$ de alt. Ramos cilíndricos, ligeiramente puberulentos, inermes. Estípulas 3-7 mm compr., lanceoladas a ovado-lanceoladas, pubescentes, persistentes. Pecíolos 3-9 mm compr., levemente canaliculados, nâo alados, pubescentes. Nectários foliares ausentes. Raque ausente. Folhas bipinadas, unijugadas; pina 3-8,4 cm compr.; foliólulos 6-8 pares por pina, $0,4-2,2 \mathrm{~cm}$ compr., $0,3-1 \mathrm{~cm}$ larg., não sensitivos, subcoriáceos, discolores, glabros ou levemente pubescentes na face abaxial, rombóide-oblongos a subfalcados, ápice agudo a obtuso, base assimétrica ou subcordada, nervuras primárias 3-4 pares, arqueado-ascendentes. Inflorescências capituliformes, axilares; pedúnculos $0,7-1,5 \mathrm{~cm}$ compr., planos a levemente cilíndricos, pubesentes; brácteas 1-3 mm compr.,
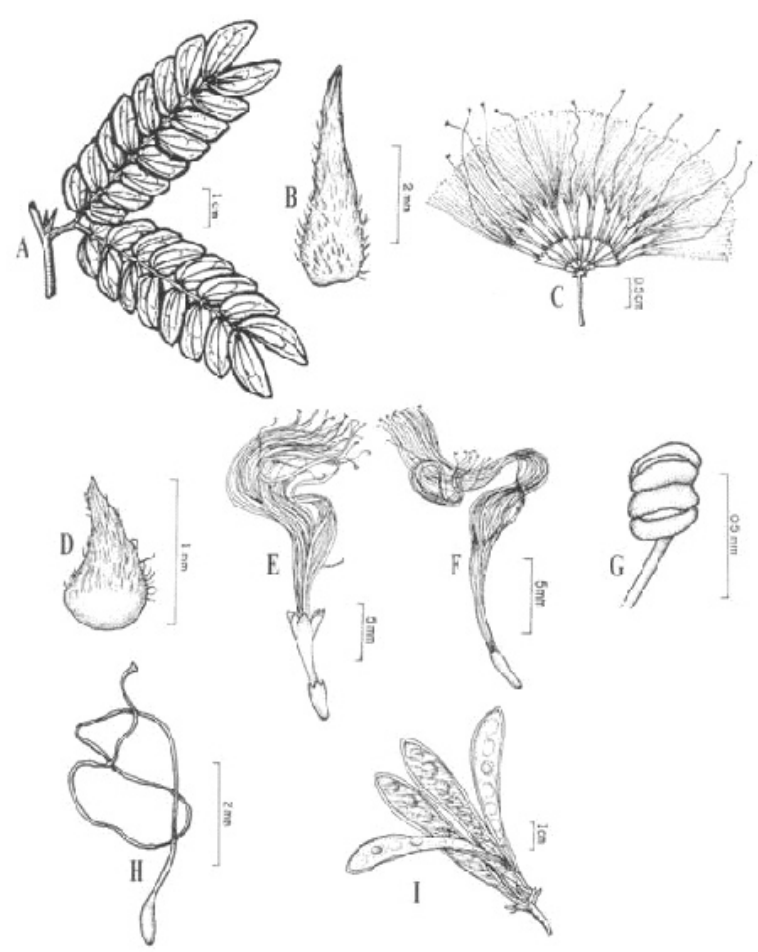

Figura 2 - Calliandra surinamensis Benth.: A. Folha e estípulas; B. Estípula; C. Inflorescência; D. Bráctea; E. Flor; F. Androceu; G- Detalhe do estame; H. Gineceu; I- Frutos.

ovadas ou subuladas, pubescentes, persistentes. Flores sésseis; cálice 2,5-3 mm compr., campanulado, lobos 5, puberulentos; corola gamopétala, 6-9 mm compr., infundibiliforme, lobos 5, glabros a ligeiramente pubescentes; estames 15-20, tubo estaminal 10-19 mm compr., exserto, filamentos livres 18-27 $\mathrm{mm}$ compr., anteras eglandulosas; ovário 1-2,5 mm compr., 0,3-0,8 mm diâm., elipsóide, glabro, estilete filiforme, excedendo os estames. Legume $40-70 \mathrm{~mm}$ compr., $8-11 \mathrm{~mm}$ larg., oblanceolado, plano ou levemente dilatado ao redor das sementes, castanho, com nervuras oblíquas, coriáceo, glabro, ápice agudo, base atenuada, margem espessa e linear.

Distribuição: Calliandra surinamensis distribui-se pela Colômbia, Venezuela, Guianas, Suriname, Equador, Peru e Brasil (AM, AC, RO, RR, PA e MA), sendo abundante em capoeira, matas, margens de rios pedregosos, campo, campinarana; em solos argilosos e arenosos (Barneby, 1998; Vieira, 1997). No litoral paraense, a espécie é comum em floresta de restinga.

Material examinado: BRASIL. Pará: Bragança, restinga, 28.IV.2006, fl. e fr., Sousa 11 (MG); Maracanã, ilha de Algodoal, restinga da praia da Princesa, floresta de restinga, 27.XI.2006, fl., Sousa et al. 15 (MG); ibidem, ilha de Maiandeua, Fortalezinha, restinga próximo ao mangue, 17.V.2007, fl. e fr., idem 17 (MG); Salinópolis, restinga, 
16.XII.1944, fl., Ducke 1679 (MG); ibidem, 25.VII.2007, fl. e fr., Sousa 51 (MG).

Nome Vulgar: "salsa".

Nas restingas do Pará, essa espécie destaca-se por apresentar folhas bipinadas unijugadas.

Foram observados indivíduos de $C$. surinamensis em floração nos meses de abril a dezembro e frutificação nos meses de abril a julho.

3. Chloroleucon acacioides (Ducke) Barneby \& J. W. Grimes, Mem. New York Bot. Gard. 74(1): 141. 1996. Figura 3

Árvore ou arbusto até ca. $10 \mathrm{~m}$ de alt.. Ramos cilíndricos, glabros, espinescentes. Espinhos 0,9-1,6 cm compr., retos ou cônicos, isolados ou geminados. Estípulas $6-10 \mathrm{~mm}$ compr., lineares ou linear-oblanceoladas, glabras, caducas. Pecíolos 0,9-1,4 cm compr., cilíndricos, não alados, pubescentes. Nectários foliares 0,5-0,8 mm diâm., cupulares. Raque 1,5-5 cm de compr., não alada, pubescente. Folhas bipinadas 5-7 jugas; pina 1,5-4,5 cm compr.; foliólulos 1036 pares por pina, 2,5-9 mm compr., 0,5-0,9 mm larg., não sensitivos, cartáceos, concolores quando jovens e discolores quando maduros, lineares a linear-oblongos, ápice agudo, base assimétrica, ciliado ao longo da margem, nervuras primárias subcentrais. Inflorescências capituliformes, axilares; pedúnculos 0,4-0,6 cm compr., cilíndricos, pubescentes; brácteas 1-3 mm compr., lineares a oblongas, com face inferior pubescente, caducas. Flores curtamente pediceladas a sésseis; cálice 1-1,6 mm compr., campanulado, lobos 5, glabros a ligeiramente pubescentes; corola gamopétala, 3-6 $\mathrm{mm}$ compr., infundibiliforme, lobos 5, papilosos; estames 10-12, tubo estaminal 0,3-0,8 cm compr., incluso, filamentos livres $0,9-1,2$ $\mathrm{cm}$ compr., anteras eglandulosas; ovário 0,5-2 mm compr., truncado, glabro, estilete filiforme, excedendo os estames. Legume nucóide 36-45 mm de compr., 10-15 mm larg., helicoidal, com suturas sinuosas irregulares entre as sementes e estrias obliquas sobre as faces, coriáceo, castanho, glabro, ápice e base agudos, margem delgada e ondulada.

Distribuição: Chloroleucon acacioides está distribuída no Suriname, Guiana Francesa e Brasil (AP, AM, PA, MT, GO, $\mathrm{MA}, \mathrm{CE}, \mathrm{PB}$ e PE), cresce em restinga, margem das matas e floresta tropical (Barneby e Grimes, 1996). Nas restingas do Pará, a espécie é encontrada na formação aberta de moitas, campo de dunas, brejo herbáceo e floresta de restinga.

Material examinado: BRASIL. Pará: Bragança, restinga, 22.IV.2006, fr., Sousa 5 (MG); Maracaná, ilha de Algodoal, 30.X.1999, fl., Lobato et al. 2471 (MG); ibidem, floresta de restinga, 27.XI.2006, fl., Sousa et al. 14 (MG); ibidem, campo de dunas, 14.XI.93, fl., Bastos et al. 1452 (MG); ibidem, 30.X.1999, fl., Lobato et al. 2471 (MG); ibidem, ilha de Maiandeua, Fortalezinha, brejo herbáceo, 03.VII.1992, fr., idem 514 (MG); ibidem, formação aberta de moitas, 17.V.2007, fr., Sousa et al. 37 (MG); Salinópolis, praia do Atalaia, campo de dunas, 26.X.2005, fl., Rocha et al. 328 (MG); ibidem, praia junto ao mangal, 17.XII.1944, fl., Ducke 1669 (IAN); São João de Pirabas, ilha de Fortaleza, campo de dunas, 15.I.1992, est., Bastos et al. 1192 (MG).

Nomes Vulgares: "esponjeira”, "jurema branca” e "pereira".

A primeira coleta desta espécie foi feita em Santarém (PA) por Ducke, que a descreveu como Pithecellobium acacioides Ducke, porém Barneby e Grimes (1996) a transferiram para o gênero Chloroleucon (Benth.) Britton \& Rose, estabelecendo a combinação Chloroleucon acacioides (Ducke) Barneby \& Grimes.

Apesar de muito comum no litoral paraense, $C$. acacioides era erroneamente identificada como Acacia farnsiana, da qual difere principalmente pelo fruto helicoidal e ovário truncado. Tal fato já havia sido salientado por Ducke (1949), quando fez alusão à semelhança dessa espécie com às do gênero Acacia Mill.

Foram observados indivíduos dessa espécie em floração nos meses de outubro a dezembro e em frutificação nos meses de abril a julho.
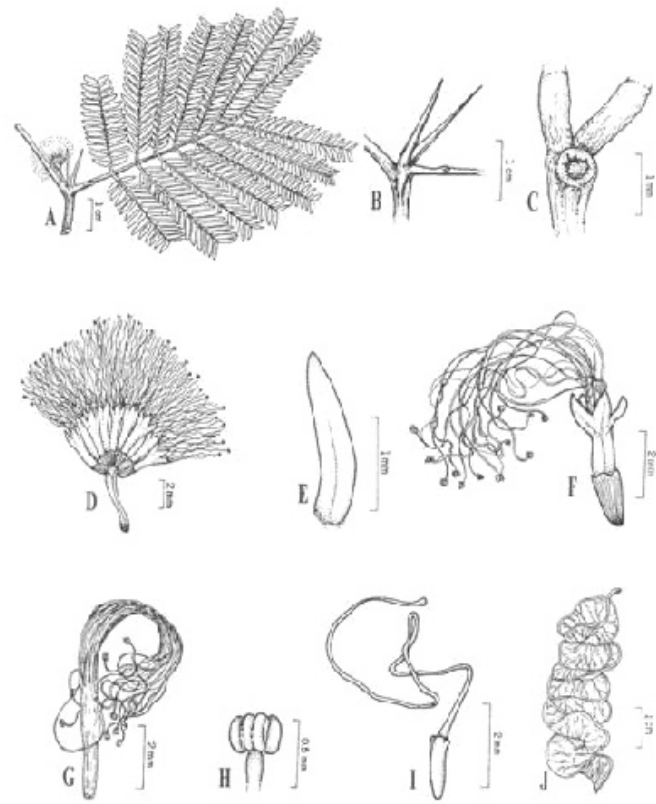

Figura 3 - Chloroleucon acacioides (Ducke) Barneby \& J.W. Grimes: A. Folha e inflorescência; B. Espinhos; C. Nectário foliar; D. Inflorescência; E. Bráctea; F. Flor; G. Androceu; H. Detalhe do estame; I. Gineceu; J. Fruto.

4. Entada polystachya (L.) DC.var. polystachya, Brittonia 48 (2): 175. 1996. Figura 4

Liana ou arbusto escandente até ca. $2 \mathrm{~m}$ de alt. Ramos cilíndricos, glabros ou ligeiramente pubescentes, inermes. 
Estípulas 1-2 mm compr., ovadas, pubescentes, caducas. Pecíolos 3,8-5,4 cm compr., subcilíndrico, não alados, lanosos. Nectários foliares ausentes. Raque 5,1-7,0 cm compr., cilíndrica a canaliculada, não alada, puberulenta. Folhas bipinadas 3-4 jugas; pina 7-13,5 cm compr.; foliólulos 6-8 pares por pina, 1,1-4 cm compr., 0,5-1,2 cm larg., náo sensitivos, subcoriáceos, discolores, oblongos, ápice obtuso a retuso, base obtusa-assimétrica, pubescente na face abaxial e glabro na adaxial, nervuras secundárias 8-10 pares, arqueadoascendentes. Inflorescências terminais em densas panículas espiciformes; pedúnculos 2-3,4 cm compr., cilíndricos, glabros; brácteas 0,5-2 mm compr., lanceoladas a ovadas, pubescentes, caducas. Flores sésseis; cálice 0,7-1 mm compr., cupuliforme, lobos 5, glabros; corola dialipétala, pétalas 5 , 1,5-3 mm compr., lineares a ovadas, glabras; estames 10 , livres, 2,5-3 mm compr., anteras com glândulas apicais caducas; ovário 1,5-2 mm compr., elipsóide, glabro, estilete tubular, excedendo os estames. Craspédio 22-27 cm compr., 6,5-7 $\mathrm{cm}$ larg., oblongo, plano ou levemente dilatado ao redor das sementes, castanho, estriado, subcoriáceo a coriáceo, glabro, ápice obtuso, base obtusa ou arredondada, margem espessa e linear, 11-18 artículos monospérmicos, réplum glabro e inerme.

Distribuição: A variedade distribui-se desde o México, América central, Pequenas Antilhas até a América do Sul, sendo registrada ao norte da Colômbia, Guianas, Equador, Bolívia e Brasil: de Roraima ao Maranhão (Barneby, 1996). Nas restingas do Pará, ocorre na formação aberta de moitas, brejo herbáceo, campo de dunas e floresta de restinga.

Material examinado: Brasil. Pará: Augusto Corrêa, restinga da APA de Urumajó, 19.X.2001, fl., Rosa Júnior et al. 34 (MG); Bragança, formação aberta de moitas, 21.IV.2006, fr., Sousa 2 (MG); Curuçá, praia da Romana, brejo herbáceo, 15.XII.1992, fl., Bastos et al. 1338 (MG); Maracaná, Fortalezinha, campo de dunas, 17.V.2007, fr., Sousa et al. 36 (MG); ibidem, floresta de restinga, 20.V.2007, fr., idem 44 (MG); ibidem, ilha de Algodoal, restinga da Princesa, campo de dunas, 26.XI.2006, fl., idem 12 (MG); Salinópolis, praia da Mina, campo de dunas, 24.X.2005, fr., Rocha et al. 276 (MG).

Nomes Vulgares: "cipó-da-beira-mar", "rabo-de-macaco" e "cipó-escova".

A variedade-tipo se diferencia das demais por apresentar folha maior, com 3-5 pares de pinas e pinas mais longas, com 6-11 pares de foliólulos, sendo os foliólulos maiores com (5) 6-20 mm de largura (Barneby, 1996).

Os caracteres diagnósticos mais úteis para o reconhecimento dessa variedade em campo foram: a inflorescência do tipo panícula espiciforme e o fruto do tipo craspédio, além de ser a única que pode se apresentar na forma de liana ou arbusto escandente, dentre as Mimosoideae das restingas paraense.
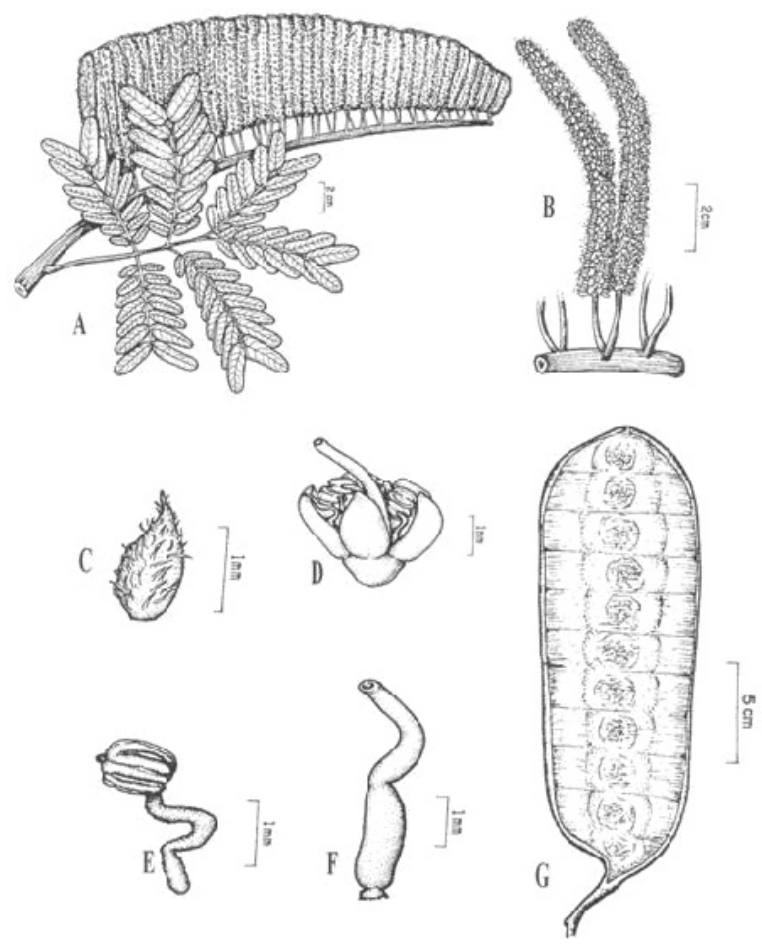

Figura 4 - Entada polystachya (L.) DC. var. Polystachya: A. Folha e inflorescência; B. Detalhe da inflorescência; C. Bráctea; D. Flor; E. Detalhe do estame com uma glândula no ápice da antera; F. Gineceu; G. Fruto.

A espécie foi observada em floração nos meses de outubro a dezembro e em frutificação nos meses de abril a outubro.

5. Inga cayennensis Sagot ex Benth., Trans. Linn. Soc. London 30: 626. 1875. Figura 5

Arbusto ou árvore até ca. $10 \mathrm{~m}$ de alt. Ramos cilíndricos, tomentosos, inermes. Estípulas 2-3 mm de compr., ovadas ou deltóides, tomentosas a vilosas, caducas. Pecíolos 0,8-1,6 $\mathrm{cm}$ compr., cilíndricos, não alados, tomentosos. Nectários foliares 0,5-1,8 mm diâm., cupulares. Raque 4-8,7 cm compr., cilíndrica, alada, tomentosa a vilosa. Folhas pinadas; folíolos 3-6 jugas, 1,1-8,6 cm compr., 0,6-4,4 cm larg., não sensitivos, cartáceos, discolores, vilosos, elípticos, ovados ou ovado-lanceolados, ápice agudo a estreitamente atenuado, base obtusa, arredondada ou assimétrica, nervuras secundárias 7-9 pares, convergente-arqueados. Inflorescências em racemos, axilares; pedúnculos $1-3 \mathrm{~cm}$ de compr., cilíndricos, tomentosos a vilosos; brácteas, 1-3 mm compr., ovadas, pubescentes, caducas. Flores pediceladas; cálice $5-9 \mathrm{~mm}$ de compr., campanulado, lobos 5, tomentosos ou vilosos; corola gamopétala, 1,1-2,5 cm compr., tubulosa, lobos 5, densamente vilosos; estames 60-80, tubo estaminal $2-4,3 \mathrm{~cm}$ compr., exserto, filamentos livres $2-4 \mathrm{~cm}$ de compr., anteras eglandulosas; ovário 1,5-3,5 mm compr., elipsóide, glabro, estilete filiforme, excedendo os estames. Legume nucóide 8,6- 
17,2 cm compr., 2,1-2,7 cm larg., reto a levemente curvado, dilatado ao redor das sementes, ferrugíneo, coriáceo, viloso, ápice e base arredondados ou obtusos, margem espessa e ondulada.

Distribuição: A espécie está distribuída na região tropical da América do Sul, ocorrendo da Venezuela ao Peru, nas Guianas, Amazônia e litoral brasileiro (Pennington, 1997), sendo comum na formaçáo aberta de moitas e floresta de restinga do litoral paraense.

De acordo com Pennington (1997), essa espécie se adapta bem a diversos ambientes, ocorrendo tanto em floresta primária úmida, como em climas mais secos.

Material examinado: BRASIL. Pará: Bragança, restinga, 26.IV.2006, fr., Sousa 9 (MG); Maracanã, ilha de Algodoal, floresta de restinga, 28.XI.2006, fl., Sousa et al. 19 (MG); ibidem, ilha de Maiandeua, Fortalezinha, floresta de restinga, 19.V.2007, fr., idem 43 (MG); ibidem, formação aberta de moitas, 20.V.2007, fr., idem 45 (MG).

Nomes Vulgares: "ingá amarelo", "ingá-de-pico" e "ingá peludo".

Inga cayennensis caracteriza-se por apresentar os lobos da corola e fruto vilosos.

Foi observada em floração no mês de novembro e em frutificação nos meses de abril a maio.

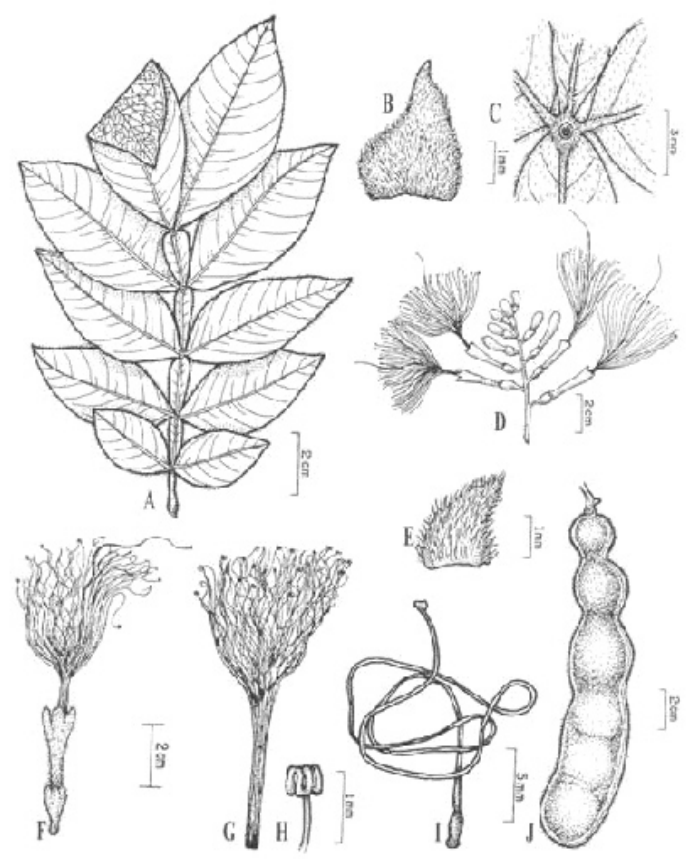

Figura 5 - Inga cayennensis Sagot ex Benth.: A. Folha; B. Estípula; C. Nectário foliar; D. Inflorescência; E. Bráctea; F. Flor; G. Androceu; H. Detalhe do estame; I. Gineceu; J. Fruto.
6. Inga heterophylla Willd., Sp. Pl. 4(2): 1020. 1806. Figura 6

Árvore de até $10 \mathrm{~m}$ de alt.. Ramos cilíndricos, glabros ou pubescentes, inermes. Estípulas 1,5-4 mm compr., lineares ou lanceoladas, glabras, caducas. Pecíolos 0,3-1,3 cm compr., cilíndricos a canaliculados, não alados, glabros. Nectários foliares 0,5-1 mm diâm., pateliformes. Raque 1,3-4,5 cm compr., cilíndrica à canaliculada, não alada, glabra. Folhas pinadas; folíolos 1-3 jugas, 4-12,5 cm compr., 1,6-3,5 cm larg., não sensitivos, cartáceos, concolores, glabros, elípticos à eliptico-lanceolados, ápice longo e estreitamente acuminado, base estreitamente atenuada ou cuneada, nervuras secundárias 6-9 pares, convergente-arqueados. Inflorescências em umbelas, axilares; pedúnculos $0,7-4 \mathrm{~cm}$ compr., cilíndricos, puberulentos; brácteas 0,7-2 mm compr., linear-espatuladas a elípticas, puberulentas, caducas. Flores pediceladas; cálice 1,5-2 mm compr., tubular, lobos 5, puberulentos; corola gamopétala, 5-8 mm compr., tubulosa, lobos 5, glabros; estames 30-40, tubo estaminal 5-7,5 mm compr., exserto, filamentos livres 6-11 mm compr., anteras eglandulosas; ovário 1-1,5 mm compr., elipsóide, glabro, estilete filiforme, excedendo os estames. Legume nucóide 8-25 cm compr., 1,4$1,7 \mathrm{~cm}$ larg., reto ou ligeiramente curvado, plano a convexo, castanho, estriado, coriáceo, glabro, ápice e base agudos, margem delgada e frequentemente ondulada.

Distribuição: Inga heterophylla está distribuída na Costa Rica, Panamá, Colômbia, Venezuela, Trinidad, Guiana, Suriname, Guiana Francesa, Equador, Peru, Bolívia e Brasil: AP, AM, AC, RO, PA, MT, SP e PR (Mobot, 2007). No litoral paraense, ocorre na formação aberta de moitas e floresta de restinga.

Segundo Pennington (1997), a espécie pode ocorrer em floresta sazonal perene, floresta primária, floresta degradada, floresta de galeria, restinga, cerrado, floresta de araucária e ao longo de margens não inundadas.

Material examinado: BRASIL. Pará: Bragança, restinga, 25.IV.2006, fl., Sousa 7 (MG); Maracanâ, ilha de Algodoal, restinga da praia da Princesa, 25.V.1994, fl., Bastos et al. 1667 (MG); ibidem, floresta de restinga, 28.XI.2006, fr., Sousa et al. 18 (MG); ibidem, formação aberta de moitas, 4.X.2006, fr., Mesquita \& Batista 11 (MG); ibidem, ilha de Maiandeua, Fortalezinha, floresta de restinga, 18.V.2007, fl., Sousa et al. 40 (MG); ibidem, formação aberta de moitas, 20.V.2007, fl., idem 46 (MG).

Nomes Vulgares: “ingá-xixi”, “ingá-xixica”, “ingá”, "ingazinho" e "pacuingá".

Inga heterophylla possui uma variação na inflorescência, que vai desde racemo até umbela. Isso tem gerado problemas em sua identificação, uma vez que é colocada na seção Leptinga Benth., a qual é caracterizada por muitos autores por 
apresentar inflorescência do tipo umbela ou capítulo (Sousa, 1993). Porém, as amostras do litoral paraense apresentaram somente inflorescência em umbela.

De acordo com Pennington (1997), essa espécie apresenta pecíolo alado próximo ao ápice, entretanto essa característica não foi observada nas amostras do litoral paraense.

No ambiente de restinga, essa espécie se caracteriza por apresentar folíolos com formatos bastante diferenciados (daí o termo heterophylla).

Foram encontrados indivíduos em floração nos meses de abril a maio e em frutificaçáo nos meses de outubro a novembro.

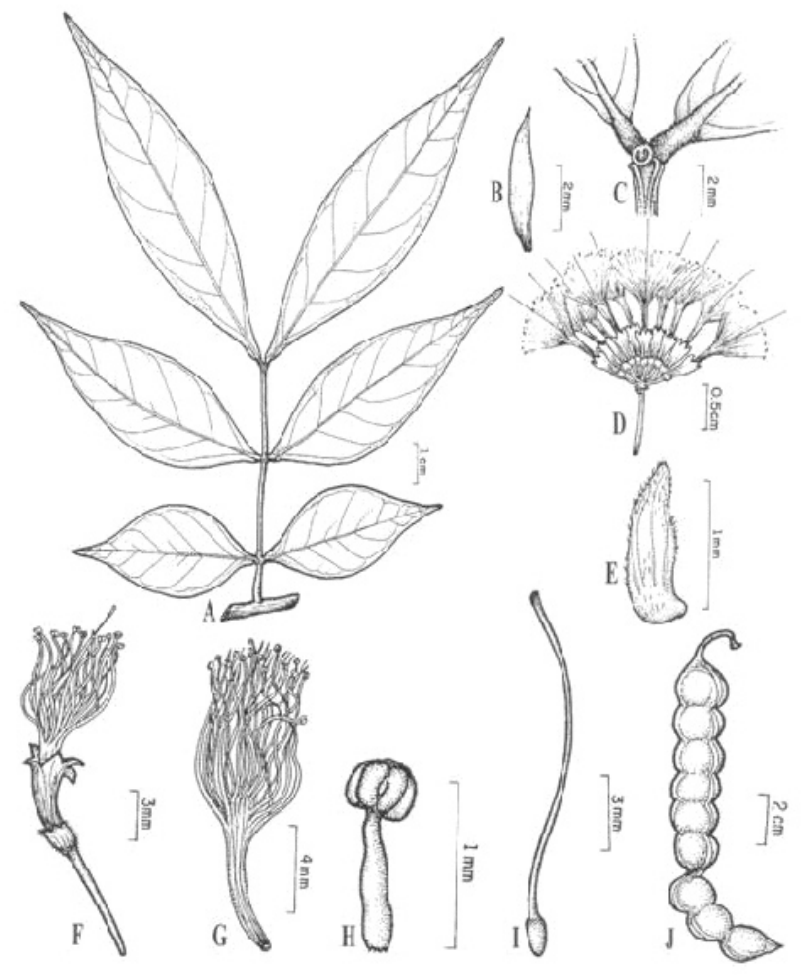

Figura 6 - Inga heterophylla Willd.: A. Folha; B. Estípula; C. Nectário foliar; D. Inflorescência; E. Bráctea; F. Flor; G. Androceu; H. Detalhe do estame; I. Gineceu; J. Fruto.

7. Inga pilosula (Rich.) J. F. Macbr., Field. Mus. Nat. Hist., Bot. Ser. 13(3/1): 41. 1943. Figura 7

Árvore até ca. $8 \mathrm{~m}$ de altura. Ramos cilíndricos, híspidos, inermes. Estípulas 2-5 mm compr., lanceoladas a elípticas, pubescentes, persistentes. Pecíolos 0,9-1,4 cm compr., cilíndricos, alados, pubescentes. Nectários foliares $0,7-2 \mathrm{~mm}$ diâm., pateliformes ou ciatiformes. Raque 1,6-3 cm compr., cilíndrica, alada, pubescente. Folhas pinadas; folíolos 2 jugas, 4,9-12 cm compr., 1,9-5,2 cm larg., não sensitivos, coriáceos, discolores, puberulentos, elípticos, ápice agudo a estreitamente atenuado, base aguda a arredondada, nervuras secundárias

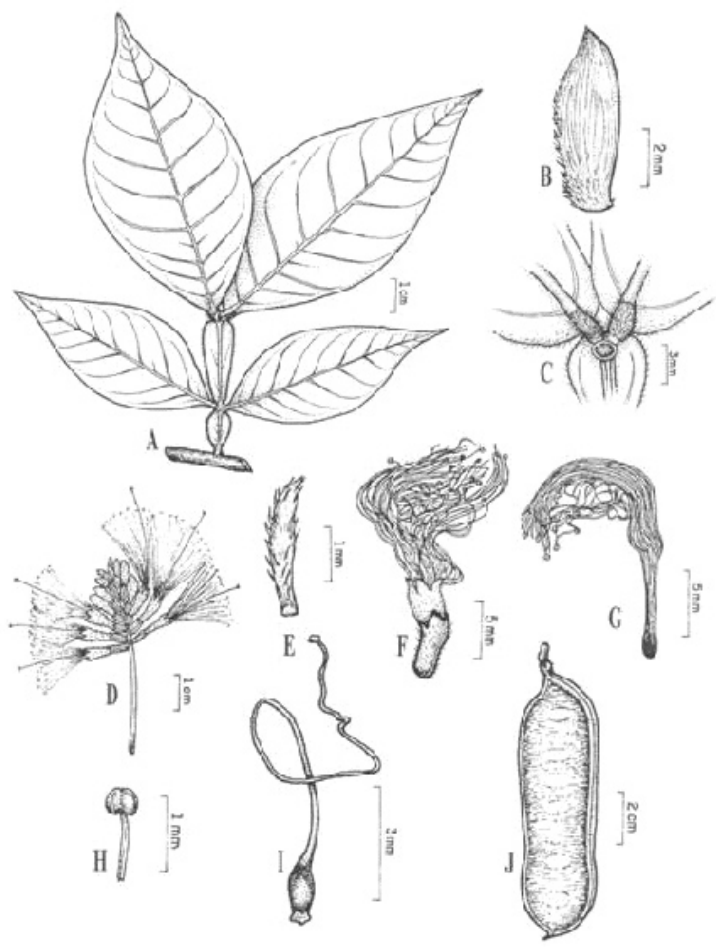

Figura 7 - Inga pilosula (Rich.) J.F. Macbr.: A. Folha; B. Estípula; C. Nectário foliar; D. Inflorescência; E. Bráctea; F. Flor; G. Androceu; H. Detalhe do estame; I. Gineceu; J. Fruto.

9-15 pares, arqueados ou retos. Inflorescências espiciformes, axilares; pedúnculos 3,2-4 cm compr., cilíndricos, pubescentes; brácteas $2-3 \mathrm{~cm}$ compr., lineares ou lanceoladas, pubescentes, caducas. Flores sésseis; cálice 5-7 mm compr., tubular, lobos 5, pubescentes a subglabros; corola gamopétala, 1,2-1,5 cm compr., tubulosa, lobos 5 , seríceos a seríceo-vilosos; estames 25-30, tubo estaminal 10-16 mm compr., incluso ou curtamente exserto, filamentos livres 1,9-2,5 cm compr., anteras eglandulosas; ovário 1,5-2 mm compr., elipsóide, glabro, estilete filiforme, excedendo os estames. Legume nucóide 6-10,5 cm compr., 2,3-2,9 cm larg., reto, plano, castanho escuro, com nervuras transversais proeminentes ou estrias recurvadas, coriáceo, glabro, ápice arredondado ou obtuso e base aguda, arredondada ou levemente truncada, margem espessa e linear.

Distribuição: Inga pilosula está distribuída na Colômbia, Venezuela, Trinidad, Guiana, Suriname, Guiana Francesa, Equador, Peru, Bolívia e Brasil: AP, AM, AC, RR, RO, PA e MA (Mobot, 2007); sendo encontrada em floresta ripária, vegetaçáo secundária e várzea, normalmente em ambientes degradados (Pennington, 1997). A espécie ocorre na formação aberta de moitas, campo de dunas e floresta de restinga, no litoral paraense.

Material examinado: BRASIL. Pará: Bragança, restinga, 27.IV.2006, fr., Sousa 6 (MG); Maracaná, ilha de Algodoal, 
praia da Princesa, 17.VI.1994, fl., Bastos et al. 1719 (MG); ibidem, 25.V.1994, bot., idem 1668 (MG); ibidem, formação aberta de moitas, 27.VIII.1995, fl., Cardim et al. 1 (MG); ibidem, floresta de restinga, 28.XI.2006, fl., Sousa et al. 17 (MG); ibidem, ilha de Maiandeua, Fortalezinha, campo de dunas, 18.V.2007, fl., idem 39 (MG); ibidem, floresta de restinga, 30.VI.1999, fl., Lobato 2443 (MG); ibidem, formação aberta de moitas, 25.VIII.1999, fl. e bot., Carreira et al. 1425 (MG); Salinópolis, praia do Atalaia, 26.X.2005, fl., Rocha et al. 329 (MG).

Nome Vulgar: "ingá".

Nessa espécie, a largura da ala da raque, os folíolos e o indumento puberulento formam um conjunto de caracteres que subsidiam a identificação dos indivíduos, mesmo quando em fase vegetativa; em frutificação, é facilmente reconhecida pelas nervuras transversais proeminentes ou estrias do legume nucóide.

A espécie foi observada em floração nos meses de maio a novembro e em frutificação no mês de abril.

8. Inga splendens Willd., Sp. Pl. 4: 1017. 1806. Figura 8

Árvore até ca. $15 \mathrm{~m}$ de alt. Ramos cilíndricos, glabros ou pubescentes, inermes. Estípulas 2-8 $\mathrm{mm}$ compr., lanceoladas, glabras ou pubescentes, caducas. Pecíolos 0,8$1,5 \mathrm{~cm}$ compr., cilíndricos, alados, glabros. Nectários foliares 1,2-2,5 mm diâm., pateliformes. Raque 1,3-3 cm compr., cilíndrica à canaliculada, alada, glabra. Folhas pinadas; folíolos 2-3 jugas, 3,5-15 cm compr., 1,9-6,8 cm larg., não sensitivos, coriáceos, subconcolores, glabros na face adaxial e ocasionalmente tomentosos na abaxial, obovados, ápice obtuso a arredondado, base obtusa, cordada ou assimétrica, nervuras secundárias 7-11 pares, arqueado-ascendentes. Inflorescências espiciformes, axilares; pedúnculos 1,8-4,5 $\mathrm{cm}$ compr., cilíndricos a canaliculados, pubescentes; brácteas 2-5 mm compr., espatuladas, pubescentes, caducas. Flores sésseis; cálice 5-12 mm compr., tubular, lobos 5, seríceos; corola gamopétala, 0,8-2,3 cm compr., tubulosa, lobos 5, seríceo-pubescentes; estames 30-60, tubo estaminal 8-23 $\mathrm{mm}$ compr., se igualando a corola, filamentos livres 1,5-2,5 cm compr., anteras eglandulosas; ovário 1,5-4 mm compr., elipsóide, pubescente, estilete filiforme, excedendo os estames. Legume nucóide 10-15 cm compr., 2,5-3 cm larg., levemente curvado, plano, castanho a quase preto, com estrias transversais proeminentes e algumas protuberâncias verrucosas, coriáceo, glabro, ápice e base arredondados, margem espessa e linear.

Distribuição: Inga splendens está distribuída na Colômbia, Venezuela, Guiana, Suriname, Guiana Francesa, Equador, Peru e Brasil: AP, AM, AC, RR, RO, PA e MT (Mobot, 2007); sendo encontrada em floresta tropical, terrenos periodicamente inundados, floresta de terra firme e margens de cursos d'água
(Pennington, 1997). No litoral do Pará, ocorre na formação aberta de moitas, campo de dunas e floresta de restinga.

Material examinado: BRASIL. Pará: Bragança, restinga, 28.IV.2006, fr., Sousa 10 (MG); Maracanã, ilha de Algodoal, restinga da praia da Princesa, floresta de restinga, 29.XI.2006, fl., Sousa et al. 21 (MG); ibidem, ilha de Maiandeua, Fortalezinha, floresta de restinga, 19.V.2007, fr., idem 42 (MG); ibidem, formação aberta de moitas, 20.V.2007, fr., idem 47 (MG); Salinópolis, praia do Atalaia, campo de dunas, 11.XI.1976, fl., Silva 2822 (MG).

Nomes Vulgares: "ingá" e "inga branco".

Inga splendens era erroneamente identificada como $I$. pilosula, porém diferencia-se desta por apresentar os folíolos obovados, com ápice obtuso a arredondado, além do ovário pubescente, enquanto $I$. pilosula apresenta folíolos elípticos com ápice estreitamente atenuado a agudo e ovário glabro.

A espécie foi observada em floração no mês de novembro e em frutificação nos meses de abril a maio.

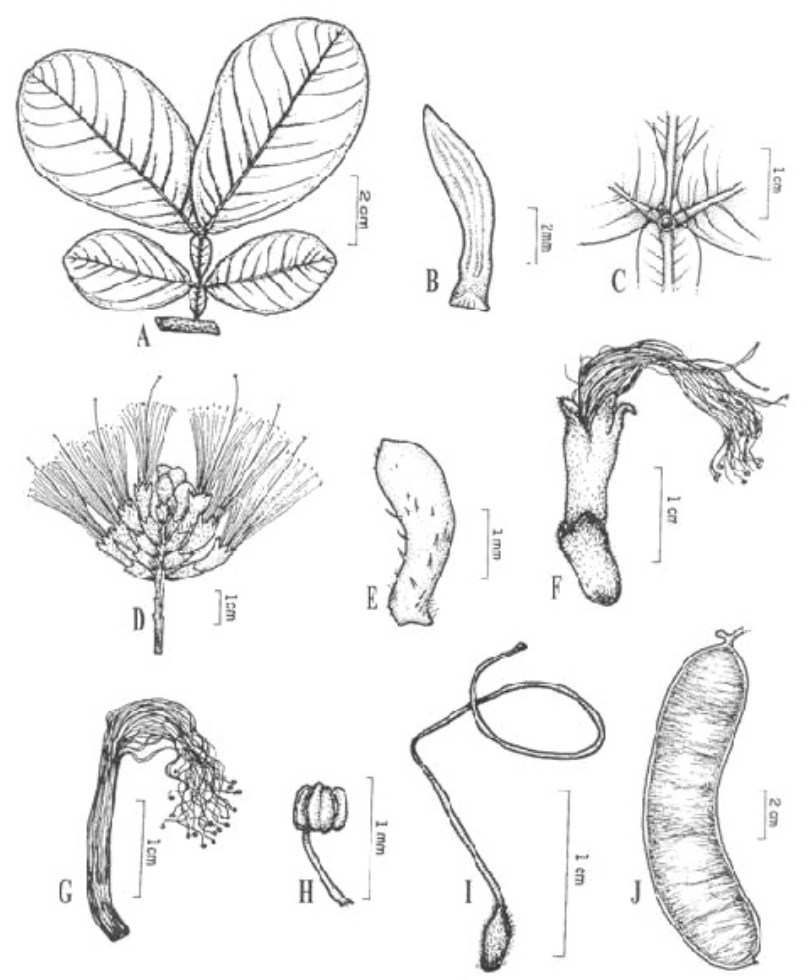

Figura 8 - Inga splendens Willd.: A. Folha; B. Estípula; C. Nectário foliar D. Inflorescência; E. Bráctea; F. Flor; G. Androceu; H. Detalhe do estame; I. Gineceu; J. Fruto.

9. Inga thibaudiana DC. subsp. thibaudiana, Prod. 2: 434. 1825. Figura 9

Árvore 4-10 m de alt. Ramos cilíndricos, pubescentes, inermes. Estípulas 1-2 mm compr., ovadas, puberulentas, caducas. Pecíolos 0,6-2,5 cm compr., cilíndricos a levemente 
canaliculados, não alados, puberulentos. Nectários foliares 1-3,5 mm de diâm., pateliformes ou ciatiformes. Raque 4,6$15,1 \mathrm{~cm}$ compr., cilíndrica, não alada, puberulenta. Folhas pinadas; folíolos 4-6 jugas, $3,5-12 \mathrm{~cm}$ compr., $1,7-5,3 \mathrm{~cm}$ larg, não sensitivos, coriáceos, subconcolores, esparsamente estrigosos na superfície adaxial, seríceo-estrigosos na superfície abaxial, elípticos a ovados, ápice agudo ou atenuado, base aguda, obtusa ou arredondada, às vezes assimétrica, nervuras secundárias 8-12 pares, retos ou arqueados. Inflorescências espiciformes, axilares; pedúnculos $0,8-2,5 \mathrm{~cm}$ compr., cilíndricos, puberulentos; brácteas $0,5-1,5 \mathrm{~mm}$ compr., ovadas, pubescentes, caducas. Flores sésseis; cálice 3,5-5 mm compr., tubular, lobos 5, pubescentes; corola gamopétala, 1,1-1,8 cm compr., tubulosa, lobos 5 , seríceos a seríceovilosos; estames 42-60, tubo estaminal 1,3-2 cm compr., incluso ou ligeiramente exserto, filamentos livres 1,5-2,2 $\mathrm{cm}$ compr., antera eglandulosas; ovário $2-3 \mathrm{~mm}$ compr., elipsóide, glabro, estilete filiforme, excedendo os estames. Legume nucóide 6,7-17 cm compr., 1,5-2,3 cm larg., reto a ligeiramente curvado, plano, castanho, com estrias transversais inconspícuas, coriáceo, velutino, ápice arredondado, base aguda ou arredondada, margem espessa e linear.

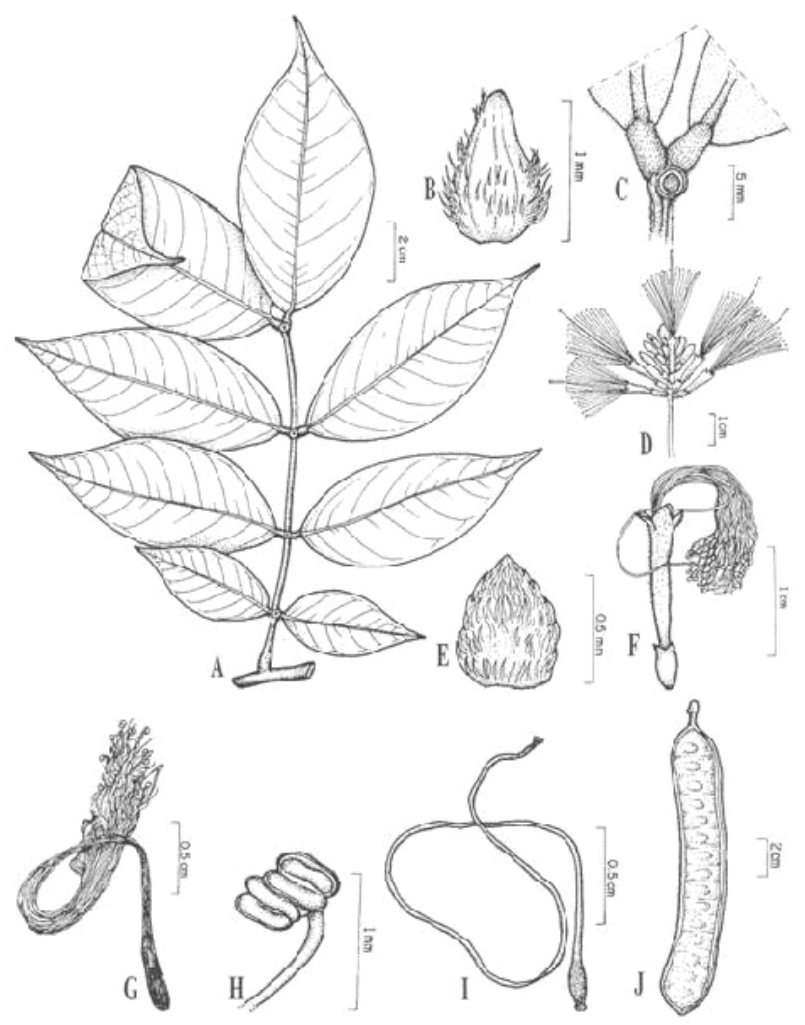

Figura 9 - Inga thibaudiana DC. subsp. thibaudiana: A. Folha; B. Estípula; C. Nectário foliar; D. Inflorescência; E. Bráctea; F. Flor; G. Androceu; H. Detalhe do estame; I. Gineceu; J. Fruto.
Distribuiçáa: A subespécie distribui-se desde o México até a regiáo tropical da América do Sul (Pennington, 1997). É comum em vegetaçáo degradada, ao longo de margens de estrada e em floresta secundária, clareiras de floresta tropical não sazonal, floresta de galeria, campina de areia branca e floresta de transição (Pennington, 1997). No litoral paraense, é encontrada no campo de dunas e floresta de restinga.

Material examinado: BRASIL. Pará: Bragança, restinga, 27.IV.2006, fr., Sousa 8 (MG); Maracanã, ilha de Algodoal, restinga da praia da Princesa, floresta de restinga, 29.XI.2006, fl., Sousa et al. 20 (MG); ibidem, ilha de Maiandeua, Fortalezinha, floresta de restinga, 19.V.2007, fr., idem 41 (MG); ibidem, campo de dunas, 20.V.2007, fr., idem 48 (MG); ibidem, restinga, 5.X.2006, fl., Furtado \& Rocha 13 (MG).

Nomes Vulgares: “ingaî”, “ingá-de-porco”, “ingá-cipó”, "ingá-da-mata" e "ingá".

Inga thibaudiana subsp. thibaudiana caracteriza-se por apresentar a raque cilíndrica, superfície inferior dos folíolos seríceo-estrigosos e fruto velutino.

Foram encontrados indivíduos dessa subespécie em floração nos meses de outubro a novembro e em frutificação nos meses de abril a maio.

10. Mimosa candollei R. Grether, Novon 10: 34. 2000. Figura 10

= Schrankia leptocarpa DC., Prodr. 2: 443. 1825.

Ervas rasteiras a trepadeiras até ca. 1,0 m de altura. Ramos tetragonais, glabros, aculeados. Acúleos 0,8-2,5 mm compr., curvados. Estípulas 3-8 mm compr., lanceoladas ou linear-atenuadas, pubescentes, persistentes. Pecíolos 1,2-5 $\mathrm{cm}$ compr., tetragonais, não alados, pubescentes, aculeados. Nectários foliares ausentes. Raque 0,6-3,3 cm compr., tetragonal, não alada, glabra a levemente pubescente, aculeada ou não. Folhas bipinadas, 2-3 jugas, pina 1,1-4,6 cm compr.; foliólulos 8-14 pares por pina, 2-10 mm compr., 1-3 mm larg., sensitivos, herbáceos, concolores, linear-oblongos a oblongos, ápice mucronado, base assimétrica, face adaxial glabra com nervuras inclusas, face abaxial puberulenta com nervuras emergentes, margem estrigosa. Inflorescências capituliformes, axilares; pedúnculos $0,5-1,5 \mathrm{~cm}$ compr., subcilíndricos, puberulentos, aculeados; brácteas $0,6-1 \mathrm{~mm}$ compr., obovadas, glabras, caducas. Flores sésseis; cálice 0,3-0,5 mm compr., campanulado, lobos 5, glabros; corola gamopétala, 2-2,5 mm compr., campanulada; lobos 5, glabros; estames 10, 4-8 mm compr., anteras eglandulosas; ovário 0,7-1,5 mm compr., oblongo a elipsóide, glabro, estilete filiforme, incluso ou exserto. Craspédio 8,9-12 cm compr., 0,3-1 cm larg., linear-tetragonal, plano, castanho, estriado, cartáceo, ápice estreitamente atenuado formando um longo rostro de 0,9-2,8 cm compr., base subaguda ou estreitamente 
quadrangular, margem espessa e linear, náo dividido em artículos monospérmicos, réplum glabro e aculeado.

Distribuição: Mimosa candollei ocorre no sul do México, América Central, Bolívia e Brasil: BA e SC (Mobot, 2007; Barneby, 1991); sendo frequentemente encontrada em ambiente degradado, ao longo de estradas e pastos abandonados (Barneby, 1991), em capoeira, margem de matas, em solos úmidos (Burkart, 1979) e campos arenosos. Nas restingas do litoral paraense, a espécie é encontrada no brejo herbáceo e campo de dunas.

Material examinado: BRASIL. Pará: Maracanã, ilha de Algodoal, restinga da praia da Princesa, campo de dunas, 29.XI.2006, fl., Sousa et al. 22 (MG); ibidem, ilha de Maiandeua, Fortalezinha, brejo herbáceo, 16.V.2007, fl. e fr., Sousa et al. 34 (MG); ibidem, restinga, próximo a vila de Fortalezinha, 21.V.2007, fl. e fr., idem 49 (MG); Salinópolis, restinga, 25.VII.2007, fl. e fr., Sousa 52 (MG).

Nomes Vulgares: "malícia-roxa" e "juquirî".
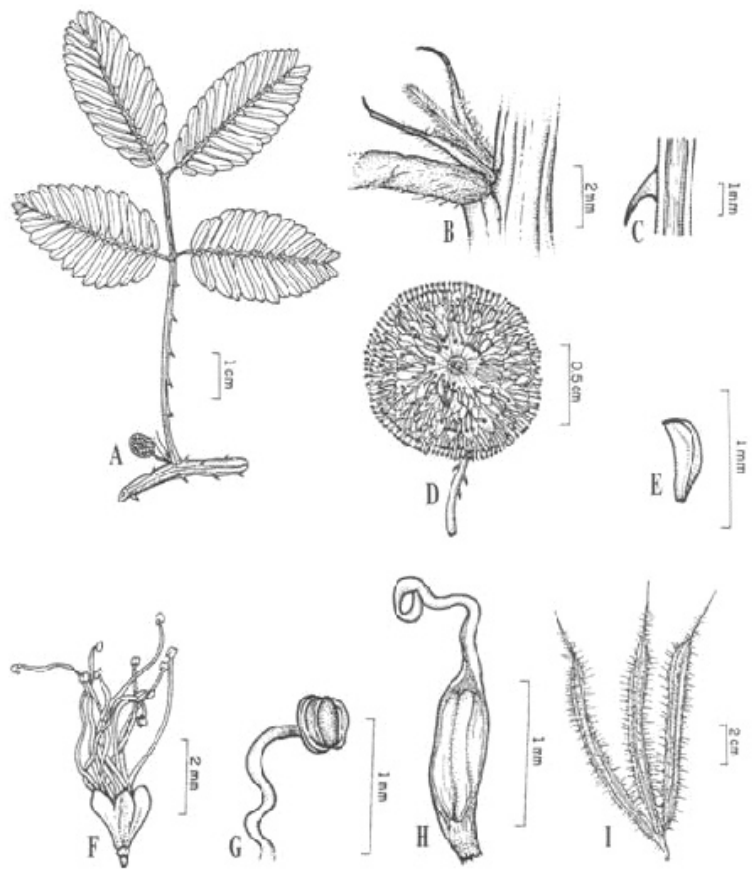

Figura 10 - Mimosa candollei R. Grether: A. Folha e inflorescência; B. Estípulas; C. Espinho; D. Inflorescência; E. Bráctea; F. Flor; G. Detalhe do estame; H. Gineceu; I. Frutos.

Esta espécie foi originalmente descrita por De Candolle (1825), que a colocou no gênero Schrankia Willd., baseandose principalmente nos caracteres tetragonais dos ramos, utilizando o material procedente de Santo Domingo. Standley (1925) a transferiu para o gênero Leptoglottis DC., e Barneby (1991) a considerou uma variedade de M. quadrivalvis $\mathrm{L}$. Atualmente Grether (2000), baseando-se nos caracteres acima mencionados, propôs o novo nome, $M$. candollei R.
Grether, uma vez que $M$. leptocarpa Rose era um nome prévia e validamente publicado.

Mimosa candollei assemelha-se a M. pudica var. unijuga, principalmente quando encontra-se estéril, entretanto é facilmente distinta por apresentar um fruto bastante característico do tipo craspédio, linear tetragonal, com a presença de um rostro longo, pericarpo dividindo-se em seçôes tetrangulares, porém não formando artículos monospérmicos.

A espécie foi observada em floração o ano todo e em frutificaçáo nos meses de maio a julho.

11. Mimosa pudica var. unijuga (Walp. \& Duchass.) Griseb., Abh. Königl. Ges. Wiss. Göttingen 7: 211. 1857. Figura 11

Erva rasteira ou escandente até ca. $60 \mathrm{~cm}$ de altura. Ramos cilíndricos, híspidos a subglabros, aculeados. Acúleos 0,5-3 mm compr., curvados. Estípulas 4-6 mm compr., linear-atenuada a ovada-lanceoladas, estrigosa-hirsutas nas margens, persistentes. Pecíolos 2-5 cm compr., cilíndricos a levemente canaliculados, glabros a híspidos, inermes. Nectários foliares ausentes. Raque 1-2,5 mm compr., cilíndrica a canaliculada, não alada, hirsuta. Folhas bipinadas, 1-2 jugas, pina 1,4-3,4 cm compr.; foliólulos 7-20 pares por pina, 2-10 mm compr., 0,6-2,6 mm larg., sensitivos, herbáceos, concolores, linear-oblongos, ápice agudo, base truncada ou assimétrica, glabros ou ligeiramente estrigosos na face abaxial e nas margens. Inflorescências capituliformes, axilares ou terminais; pedúnculos 1-1,7 cm compr., cilíndricos, glabros a ligeiramente híspidos; brácteas $0,5-1 \mathrm{~mm}$ compr., lineares, glabras, persistentes. Flores sésseis; cálice 0,2-0,4 mm compr., campanulado, lobos diminutos, glabros; corola gamopétala, 1,5-2,5 mm compr., subtubulosa, lobos 4, glabros; estames 4, filete 5-7 mm compr., exserto, anteras eglandulosas; ovário 0,40,8 mm compr., elipsóide, glabro, estilete filiforme, excedendo os estames ou se igualando aos mesmos. Craspédio 10-15 mm compr., 2-4 mm larg., oblongo, plano ou levemente dilatado ao redor das sementes, castanho, estriado, subcoriáceo, ápice e base obtusos a arredondados, margem delgada e ondulada, 2-4 artículos monospérmicos, réplum híspido e inerme.

Distribuição: A variedade distribui-se pela bacia do Caribe, Bahamas, Golfo do México e América Central. Na América do Sul ocorre de forma descontínua da Colômbia até oeste do Equador e desde Trinidad até as Guianas. No Brasil, ocorre descontinuamente do Pará até a Bahia. É encontrada isolada no norte e leste da Bolívia, sendo extensivamente naturalizada na Ásia, Sri Lanka, Polinésia e África tropical (Barneby, 1991), ocorrendo como ruderal, em ambientes antropizados. No litoral paraense, é encontrada no brejo herbáceo e campo de dunas. 
Material examinado: BRASIL. Pará: Maracanã, ilha de Algodoal, restinga da praia da Princesa, brejo herbáceo, 27.XI.2006, fl., Sousa et al. 16 (MG); ibidem, ilha de Maiandeua, Fortalezinha, restinga, brejo herbáceo, 16.V.2007, fl. e fr., idem 33 (MG); ibidem, campo de dunas, 21.V.2007, fl. e fr., idem 50 (MG).

Nomes Vulgares: "juquiri", "malícia” e "maria-fechaporta".

Mimosa pudica var. unijuga difere das demais variedades por apresentar corola glabra e brácteas florais marginalmente glabras a setulosas (Barneby, 1991). Na restinga, é facilmente reconhecida por apresentar foliólulos sensitivos, quatro estames, corola com quatro lobos e fruto do tipo craspédio.

Essa variedade floresce o ano todo e frutifica no mês de maio.

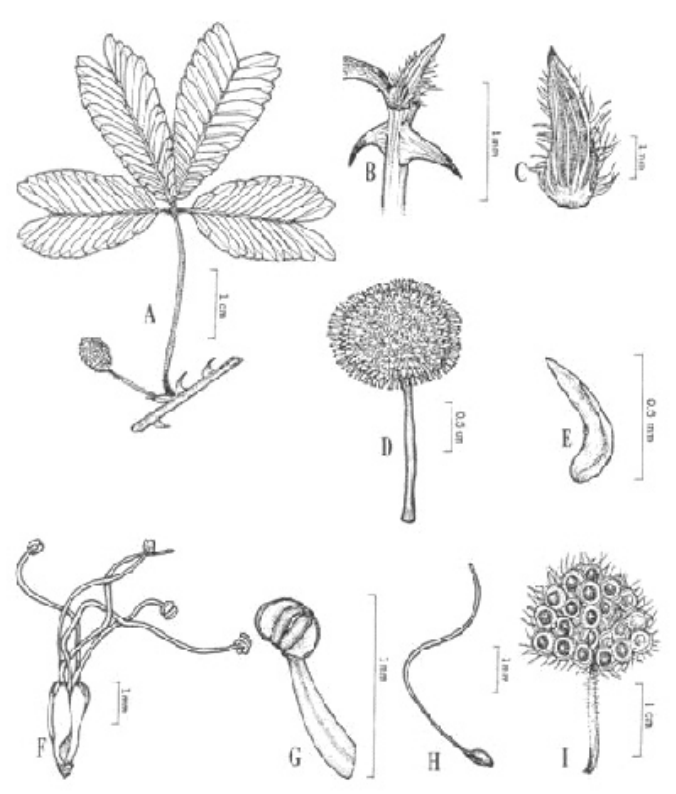

Figura 11 - Mimosa pudica var. unijuga (Walp. \& Duchass.) Griseb.: A. Folha e inflorescência; B. Espinhos e estípula; C. Estípula; D. Inflorescência; E. Bráctea; F. Flor; G. Detalhe do estame; H. Gineceu; I. Frutos.

\section{CONCLUSÕES}

Os dados contrastam com o levantamento preliminar feito na coleção dos herbários MG e IAN, que apresentou apenas cinco táxons para as restingas do Pará. Tal fato deve-se à baixa intensidade de coleta na área, além da desatualização taxonômica das coleçóes.

Os táxons: Inga thibaudiana subsp. thibaudiana e Mimosa candollei, constituem novos registros para as restingas do Estado do Pará.

Devido a maioria das espécies ser de porte arbustivo ou arbóreo, os seus indivíduos estão mais distribuídos nas porçôes internas da restinga, onde se observa um ambiente um pouco mais úmido e solos mais consistentes, inclusive com formação de fina camada de serrapilheira e estratos de sub-bosque, como na formaçáo floresta de restinga. Esta formaçáo foi a que apresentou a maior ocorrência de espécies, nove das 11 levantadas.

Entada polystachya var. polystachya e Chloroleucon acacioides apresentaram distribuição mais ampla na área, desde o brejo herbáceo até a floresta de restinga, enquanto que Calliandra surinamensis só foi encontrada em floresta de restinga.

Nas formaçôes halófila e psamófila reptante não foi observada a ocorrência de táxons dessa subfamília.

\section{BIBLIOGRAFIA CITADA}

Amaral, D.D.; Prost, M.T.; Bastos, M.N.C; Costa Neto, S.V.; Santos, J.U.M. 2008. Restingas do litoral amazônico, estados do Pará e Amapá, Brasil. Bol. Mus. Para. Emílio Goeldi, 3(1): 35-67.

Barneby, R.C. 1991. Sensitivae censitae: a description of the genus Mimosa Linnaeus (Mimosaceae) in the New World. Mem. N. Y. bot. Gdn., 65: 1-835.

Barneby, R.C. 1996. Neotropical Fabales at NY: Asides and oversights. Brittonia, 48: 175

Barneby, R.C.; Grimes J.W. 1996. Silk tree, Guanacaste, Monkey's Earring: a generic system for the synandrous Mimosaceae of the Americas. part I. Abarema, Albizia, and allies. Mem. N. Y. bot. Gdn., 74(1): 85 .

Barneby, R.C. 1998. Silk tree, guanacaste, monkey's earring: a generic system for the synandrous Mimosaceae of the Americas. Part III. Calliandra. Mem. N. Y. bot. Gdn., 74(3): 76.

Barroso, G.M.; Peixoto, A.L.; Costa, C.G.; Ichaso, C.L.F.; Guimarães, E.F.; Lima, H.C. 1991. Leguminosae. In: Sistemática de angiospermas do Brasil. Vol. 2. UFV, Viçosa. p. 15-100.

Barroso, G.M.; Morim, M.P.; Peixoto, A.L.; Ichaso, C.L.F. 1999. Leguminosae. In: frutos e sementes: morfologia aplicada à sistemática de dicotiledôneas. UFV, Viçosa. p. 168-221.

Burkart, A. 1979. Leguminosas; Mimosoideas. In: Reitz, P.R. Flora ilustrada Catarinense, Part. 1. p. 49-83.

Costa Neto, S.V. 1999. As formaçôes herbáceas da restinga do Crispim, Marapanim-Pará. Dissertação de Mestrado, Faculdade de Ciências Agrárias do Pará, Belém, Pará. 120pp.

De Candolle, A.P. 1825. Leguminosae. Prodr. Syst. Natur. Reg. Veg., 2: $93-524$.

Ducke, A. 1949. As Leguminosas da Amazônia Brasileira. Bol. Tec. IAN., 18: 15-71.

Fidalgo, O.; Bononi, V. L. R. 1984. Técnicas de coleta, preservação $e$ herborização do material botânico. Instituto de Botânica, São Paulo. 62pp.

Furtado, L.G. 1987. Curralistas e redeiros de Marudá: pescadores do litoral do Pará. Museu Paraense Emílio Goeldi, CNPq, Belém, Pará, Brasil. 366pp.

Garcia, F.C.P. 1998. Relaçôes sistemáticas e fitogeográficas de Inga Mill. (Leguminosae-Mimosoideae) nas florestas da costa sul e sudeste do 
Brasil. Tese de Doutorado, Universidade Estadual Paulista, Rio Claro, São Paulo. 248pp.

Grether, R. 2000. Nomenclatural changes in the genus Mimosa (Fabaceae, Mimosoideae) in Southern Mexico and Central America. Novon, 10: 34

Harrington, H. D.; Durrel, L. W. 1957. How to identify plants. Sawllow Press, Chicago. 203pp.

Irwin, H.S.; Barneby, R.C. 1982. The American Cassiinae: a synoptical revision of Leguminosae tribe Cassieae subtribe Cassinae in the New World. Mem. N. Y. bot. Gdn., 35(1-2):11918.

Lewis, G.P. 1987. Legumes of Bahia. Royal Botanic Gardens, Kew. 369pp.

Lewis, G.P; Schrire, B.; Mackinder, B; Lock, M. 2005. Legumes of the world. Royal Botanic Gardens, Kew. 577pp.

Lima, H.C. 2000. Leguminosas arbóreas da mata Atlântica - uma análise da riqueza, padróes de distribuição geográfica e similaridades florísticas em remanescentes florestais do Estado do Rio de Janeiro. Tese de Doutorado, Universidade Federal do Rio de Janeiro, Rio de Janeiro. 122pp.

Mobot, 2007. Missouri Botanical Garden, W3MOST. (www.mobot. mobot.org/W3T/Search/vast.html). Acesso: 04/05/07.

Pennington, T.D. 1997. The genus Inga botany. Royal Botanic Gardens, Kew. 844pp.

Polhill, R.M.; Raven, P.H. 1981. Adavances in legume systematics. Royal Botanic Gardens, Kew. 1049pp.

Radford, A.E.; Dickison, W.C.; Massey, J.R.; Bell, C. R. 1974. Vascular plant systematics. Harper e Row, New York, 891pp.
Rizzini, C.T. 1977. Sistematização terminológica da folha. Rodriguésia, 29(42): 103-125.

Silva, M.F.; Souza, L.A.G. 2002. Levantamento das Leguminosas do arquipélago das Anavilhanas, baixo rio Negro, Amazonas. Bol. Mus. Para. Emílio Goeldi, 18(1): 3-35

Sousa, M. 1993. El género Inga (Leguminosae - Mimosoideae) del sur de México y Centroamerica, estudio prévio para la Flora Mesoamericana. Ann. Mo bot. Gdn., 80: 223-269.

Souza Filho, P.W.M.; Cunha, E.R.S.P.; Sales, M.E.C.; Souza, L.F.M.O.; Costa, F.R. 2005. Bibliografia da Zona Costeira Amazônica. Museu Paraense Emílio Goeldi, Universidade Federal do Pará, Petrobrás, Belém. 401pp.

Souza, V. C.; Lorenzi, H. 2005. Botânica sistemática: guia ilustrado para identificação das famílias de angiospermas da flora brasileira, baseado em APG II. Nova Odessa: Instituto Plantarum, p 291328.

Standley, P.C. 1925. Trees and shrubs of México. United Satates National Museum-Smithsonian Institution, Washington. p $171-515$.

Stearn, W.T. 1992. Botanical Latin. 4. ed. Oregon, Portland. 546pp.

Vieira, M.G.G. 1997. A tribo Ingeae Bentham (Mimosaceae) na reserva florestal Ducke, Manaus, AM. Tese de Doutorado, INPA, UFAM, Manaus, Amazonas. 355pp.

Recebido em 10/09/2008

Aceito em 18/08/2009 
